\title{
AN ANALYSIS ON READABILITY OF ENGLISH READING TEXTS FOR GRADE IX STUDENTS AT MTSN 2 KOTA BENGKULU
}

\author{
Yupika Maryansyah \\ Program Studi Pendidikan Bahasa Inggris \\ Universitas Muhammadiyah Bengkulu \\ Email: yupiedu@gmail.com
}

\begin{abstract}
:
There are many researches on readability of reading materials conducted by reading material experts, but very few investigating readability of reading materials used in teaching reading at state-owned Islamic secondary schools. This research dealt with readability of texts used in teaching reading for IX grade students of a state-owned Islamic secondary school. This research is a descriptive research which used quantitative method. It aimed at investigating the readability of texts used in teaching reading for IX grade students of MTsN 2 Kota Bengkulu. The subjects of this research were 63 texts used in teaching reading for IX grade students at MTsN 2 Kota Bengkulu. The instrument used to collect data was Fry readability formula (graph). The data were interpreted by using percentage.

The research findings show that 54\% out of 63 texts are easy for grade IX students of MTsN 2 Kota Bengkulu; 27\% out of 63 texts are difficult; $10 \%$ out of 63 texts are invalid; and 9\% out of 63 texts are appropriate. Based on the research findings, there are some suggestions to note; (1) English teachers at MTsN 2 Kota Bengkulu are suggested to apply readability analysis on texts before they are used in teaching reading; (2) Writers of English textbooks which are intended to be used by grade IX students are suggested to be aware of readability of texts they included into the textbooks they wrote; and (3) other researchers are suggested to conduct further researches on the findings of this research by employing other readability formulas, or other methods of readability analysis.
\end{abstract}

Keywords: Tingkat readibilty, text, MTsN 2 Kota Bengkulu.

\section{INTRODUCTION}

This is a readability study on reading materials used for teaching reading at MTsN 2 Kota Bengkulu. It purposed to explain readability of texts used in teaching reading for Grade IX students at MTsN 2 Kota Bengkulu. The study was focused on the problem of the absence of any applied appropriateness analysis on the selected textbooks before they were used for teaching. A problem that leads to uncertainty of readability level of texts used for Grade IX learners of MTsN 2 Kota Bengkulu. As broadly known, teachers are not encouraged to simply pick a text without knowing whether the text is appropriate or not for their students. 
This is a strong reason of the urgency to conduct a readability analysis toward texts in the textbooks selected by teachers at MTsN 2 Kota Bengkulu.

Madrasah Tsanawiyah Negeri (MTsN) 2 Kota Bengkulu is a state-owned Islamic Secondary Schools in Bengkulu. In running English teaching and learning process, by the time when this study was being conducted, MTsN 2 Kota Bengkulu employed 5 English teachers; 3 were civil servant teachers and the other 2 were part-timers English teachers. In case of selecting teaching materials, based on the researcher's observation, all of these teachers simply picked some textbooks for teaching. Without any analysis before using, these textbooks were utilized in teaching English at this school.

Regarding to teaching material selection mechanism stated above, there are some interrelated problems to infer. First, teachers worked without any scientific procedures in determining texts (reading materials) for their students. The process of simply picking a textbook to teach, particularly in teaching reading, is a mechanism that is based on a weak and less scientific basis. Second, since there was not any analysis applied on texts on the selected textbooks, then scientifically, nobody knows whether texts in those textbooks are easy, difficult, appropriate or inappropriate for the learners who use them. This situation is risky for learners in term of reading theories' point of view. Third, most of the students of MTsN 2 Kota Bengkulu frequently failed to reach the expected reading comprehension achievement. It is interesting to figure out that a third grade English teacher of MTsN 2 Kota Bengkulu mentioned that most of her students failed to answer 7 of 10 questions of a text entitled Radio in a textbook, Let's Talk published by Pakar Raya Press. Regarding to this case, perhaps, because the text is too difficult (or even too easy) for students, then it indirectly affects students' reading comprehension achievement.

As was mentioned in the previous part, we are acknowledged that there are some principle problems on the process of selecting textbooks, including texts for teaching reading, currently occurs at MTsN 2 Kota Bengkulu. As teachers of English, we all realize the importance of choosing text that our student can read and understand; if a text is too difficult,

student may become frustrated and turn away from the topic. The teacher, therefore, in her role as organizer, director, stimulator and evaluator of individual learning must be aware of problems associated with printed materials.

\section{REVIEWS OF RELATED LITERATURES}

The construction of this study was built by some interrelated principal basic theories in teaching reading, namely; concept of reading, concept of teaching reading, concept of text, 
and concept of readability. From concept of reading point of view, there are two prominent ideas has become consideration of the study, which are definition of reading and views in reading. Many experts of reading suggest that reading is not simple process. It can be noticed by a very wide range definition of reading. For instance, the one suggested by Carrol (1964) who mentions that reading is reconstructing a reasonable spoken message from a printed text, and making meaning responses to the reconstructed message that parallel to the spoken message. Another one is Grellet (1981) who states that reading is extracting information the required information from text as efficiently as possible. This definition straightforwardly emphasize that reading involves constructing meaning from written text. Additionally, there are still many more definitions having the same tone such as definition by Koda (2004), Wolf (2007), and Smith (2004). After all, these wide range and varied definitions of reading indicate that reading is a complex and multifaceted process.

In spite of the complexity of reading, there are some fundamental views on reading. According to Hedgcock and Ferris (2009) there are three basic views in theory of reading, namely; bottom-up views, top down views, and interactive (or integrative) views. In bottomup views, reading is started the bottom level of text structure, from discrete, visual unit such as graphemes, morphemes and words. Top-down views of reading assume that reading is primarily directed by reader goals and expectations. Readers start reading process with expectation about texts and the information that texts present. Whereas, Interactive (or integrative) views of reading take the ideas from bottom-up perspective and combine them with key ideas from top-down view. It is obvious that this view is a sort of combination between both of the prior models, bottom-up and top-down views. These three views are different in focus; bottom-up views focus on text; top-down views focus on reader; and interactive (or integrative) views focus on both; text and reader. They provide a very wide range discussion on how a reader interacts with a given text while she is reading which enables us to analyze reading from many different points of view.

In concept teaching reading, many literatures discuss a point that teaching reading is not simple involving many contributing factors. One of them is was suggested by Brumfit et.al (1978) that says that teaching reading involves at least four contributing factors; teaching approach, teaching aids, appropriate text, and aspects of reading (e.g. words, grammatical constructions, and rhetorical elements, and so forth). This point of view seems to be limited. However, it clearly includes some elements of classroom reading. Teaching approach will allow teachers package teaching properly. Teaching aids will help learner comprehend reading materials. Whereas, appropriate text (including aspects of text), will also important in 
building up learners' reading competence. A text which is too difficult, where every word has to be explained, or which uses extremely complex grammatical construction, or which is about some obscure technical subject of small interest to learner, is only likely to produce frustration. Similarly, a text which is too easy does not extend the learner and it is fundamental that learning require effort.

Regarding the discussion on text, a variety of definitions of text have been advanced by reading theorist, linguist, and specialist in text analysis. One general definition of a text is "a verbal record of a communicative record (Brown and Yule, 1983)." According to Wallace (1993), text is the physical manifestation of language. Furthermore, Grab and Kaplan (1996) states that a text is a sample of written language that has unified meaning. The latest definition comes from Hedgcock and Ferris (2009) which is "a collection of random words or sentences, even if they are formatted to appear visually cohesive."

Brown and Yule's definition implies that a text could be either being written or transcribed version of speech. Wallace's definition includes not only orthographic symbols such as letters of the alphabet but also non verbal elements such as capitalization, paragraphing, formatting, and so on. Grab and Kaplan and Hedgcock and Ferris's definition seems to be in one tone since both are emphasizing meaning and word.

Brown and Yule (1983) fractioned text into two, which are; written and spoken text. Written text is what he states as text as printed record, while spoken text is text as a taperecording of a communicative act. In teaching and learning reading process, definitely the prior one is mostly utilized by teachers to teach as well learners to comprehend. This written text are frequently presented in form of different editions, different type-face, on different size of paper in one or two columns etc. (Brown and Yule, 1983).

Comprehending a text is not simple process, as well as teaching learners to comprehend a text. Experts in reading had dealt with text to find ways of how to ease learner and teacher work out learning and teaching reading through the discussion of text. Brown (2000) for instance, by using different term which he calls as written language, which eventually refers to the same point, that is text, states that written language has characteristics, such as; permanence, processing time, distance, orthography, complexity, vocabulary, and formality. Brown argues that these characteristics may help teacher in; diagnosing certain reading difficulties arising from idiosyncrasies of written language or text; pointing technique toward specific objectives; and reminding learners of some of the advantages of the written language or text. 
Alternatively, teachers may identify the genre of a text to help them in teaching reading. When a writer presents her ideas into a text, she will be much influenced by her own culture and purpose, and those are reflected in the genre of text he wrote. As Gerot and Wignell (1994) argues that genre can be defined as a culturally specific text-type which result from using language (written or spoken) to (help) accomplishing something. They also state that genres have associated with them; particular purposes; particular stages (distinctive beginnings, middles and ends); and particular linguistic features. Further, Gerot and Wignell propose several kinds of genre and their characteristics. According to them, the term characteristic here is not static, rigid or fixed, but potentially represent most genres are. Whereas, Brown (2000) also proposes some kinds of genres even they are very straightforwardly simple and uncharacterized such as; fictions, non-fictions, letters, greeting cards, memos, messages, announcements, directions, labels, signs, recipes, manuals, invitations, and etc.

The effort of easing teacher in teaching reading also demands preventive action before deciding which text to use. This should be done to obtain appropriate text for particular group of learners; otherwise, the text may be too easy or too difficult for them. In dealing with this matter, Hedgcock and Ferris (2009) provide several considerations before selecting a text for secondary learners. They argue that the variables bellow should be put in consideration when a teacher selects text for their learners;

1. Text length (both individual text and course reader)

2. Extra-textual characteristics (vocabulary glosses, pictures, headings, special text; formatting; audio, video, graphics and hyperlinks in digital text)

3. Vocabulary (proportion of unfamiliar content-specific, general, and academic words; frequency of occurrence; helpfulness of surrounding contexts)

4. Morphology (inflectional and derivational morphemes that could assist readers with sentence processing and word analysis)

5. Syntax (sentence length/complexity, sentence type, "advanced" structure such as passive constructions, relative clauses, and so on)

6. Explicit cohesive devices such as connectives and referential ties

7. Text macrostructure; logical ordering of ideas, transparency of logical relations, and overall discourse structure

Regarding the seven considerations on selecting text proposed by Hedgcock and Ferris, planning a lesson for reading may become a hard work for a teacher. The seven considerations are all important in selecting a text. Teacher should carefully analyze text 
before it is taught to her learners. After all, the discussion on concept of text above implies that text has numerous elements and information types. Consequently, in planning a lesson in teaching reading, a teacher could not just pick or select any text without any strong analysis and consideration. She may work with a specific text for several days or even weeks. Thus a careful analysis of that text is extremely important for the success of that lesson.

No matter how much an English teacher learns about her learners' reading skill and attitude, she needs to evaluate books, modules, or materials she is going to ask her learners to read. If materials are too easy, students are unchallenged and bored, and no learning occurs; if materials are too difficult, students are frustrated and withdrawn, and again no learning occurs (Carrell, 1987). If the teacher does not evaluate the materials she expects learners to read, she may be presenting her learners with reading that is far too difficult, too easy, too inaccessible, or too unfriendly. It is important to note that a good fit between learners and the texts to be read is crucial. Instrument which is available to help teachers engage in this matter is a concept called as readability.

Readability may be viewed either as legibility, interest, or ease of comprehension; and the terms readability and legibility are sometimes used interchangeably to mean ease and speed of reading printed material. Readability may be used to mean understanding or comprehension of the printed text. Such elements as vocabulary and sentence structure, percentage of hard words, and long sentences distinguish between those persons who are literate and those who are highly literate.

All three aspects of readability; interest, legibility, and ease of understanding are related to one another. Interest sometimes depends as much on mechanical factors such as size and style of type, length of reading material, drawings or graphs as it does on the subject matter and themes used. Comprehensibility may be a determinant of interest. A book that is too difficult may lose its appeal, even though it is inherently interesting to the reader. Ease of reading, or understanding, depends often on the reader's interest in the subject matter. Factors of format, such as good paragraphing, introductory phrases in bold type, and short chapters facilitate the understanding of the reader.

There are some broadly known definitions of readability. The first is suggested by Dale and Chall (1949). They define readability as the sum total (including all the interactions) of all those elements within a given piece of printed material that affect the success a group of readers have with it. The success is the extent to which they understand it, read it at an optimal speed, and find it interesting. Nineteen years later, Klare (1968) states many validity studies of readability formulas indicates that the readability of a passage or text can be 
operationally defined in terms of; efficiency of reading, reader judgment, and comprehension and learning. These definitions are drawn based on variables which are measured by a particular formula.

The creator of the SMOG (Simple Measure of Gobbledygook) readability formula, McLaughlin (1969), defines readability as the degree to which a given class of people finds certain reading matter compelling and comprehensible. This definition stresses the interaction between text and a class of readers of known characteristics such as reading skill, prior knowledge, and motivation. Richard and Schmidt (2002), state that readability is how easily written materials can be read and understood. They add that readability depends on many factors, such as; the average length of sentences in a passage, the number of new words a passage contains, and the grammatical complexity of the language used. This definition mentions some factors that may affect a readability of a given material. Furthermore, Pikulski (2002) suggests that readability is the level of ease or difficulty with which text material can be understood by a particular reader who is reading that text for a specific purpose. Readability is dependent upon many characteristics of a text and many characteristics of readers. The last definition is suggested by Fry (2002), he defines readability as an objective numerical score obtained by applying a readability formula. Fry's definition is very formulaic and specific.

All definitions above are varying in some senses. However, all of them describe a general impression that we can catch. One important characteristic of a useful informed definition of readability is that it reflects the interactive nature of the construct. Interaction between reader and particular reading material is a foremost consideration in readability. Additionally, there are factors which affect readability from both; reader and material read (books or texts). These all are important which must be taken into account in measuring readability

Chall (1996) suggests that there are three approaches on measuring readability; the classic, cognitive-structural, and holistic-judgment approach. Essentially, the classic readability approach measures use similar factors to predict comprehension difficulty; aspects of word difficulty measured either as word familiarity, word frequency, abstract versus concrete words, or word length; number of syllables, number of letters, or affixes, etc. And some measures of sentence complexity, measured either by average sentence length, or by complex versus simple sentences. Cognitive-structural approach maintains that the notion of readability is an interaction between texts and readers and that difficulty in reading stems from locating and maintaining relationships between ideas. This means that the approach 
more concerns about deep structure of a written materials. Whereas, the holistic-judgment approach is based on judgment and assessment method of readability. It employs qualitative, holistic assessment which concerns great variety of text variables including vocabulary, syntax, conceptual load, text structure, and cohesion that differentiate the levels of texts.

Oakland and Lane (2004) state that basically there are two approaches in measuring readability of text, which are; quantitative and qualitative approaches. This is also suggested by Ulusoy (2006). They agreed that quantitative approach is the approach in measuring readability which relies on two quantitatively measured qualities; vocabulary (e.g., typically assessed by word familiarity and/or the number of letters or syllables within a word) and syntax (e.g., typically assessed by sentence and paragraph length and/or sentence and passage complexity). This approach is mostly represented by readability formulas. On the other hand, qualitative approach is the approach in measuring readability which concerns about some important text variables such as structure, coherence and cohesion; and important reader variables such as prior knowledge, interest, motivation and purpose for reading, and idea density and conceptual difficulty. Additionally, Ulusoy (2006) suggests combination of both; quantitative and qualitative approach in measuring readability of a passages, texts or even books to accommodate all aspect of an assessed material.

The greatest difference among these approaches is in their primary concern for either practice or theory. The cognitive-structural and qualitative approaches of readability focus most heavily on theory, specifically on cognitive and linguistic theory. While the classic readability; holistic-judgment; and quantitative approaches are concerned more with practical use. To sum up, they are all have the same goal but different on practice. Thus, for the user of readability formulas, no matter the approach is, all of them are acceptable scientifically. It depends on the users to concerns; whether much more concerns to the theory or the practice.

\section{Fry readability formula}

Fry Readability Formula is original graph determines readability in reading grade levels. Edward Fry introduced the Fry Graph as a way to predict the readability of a text. He created the formula in 1968 while working as a Fullbright scholar in Urwanda teaching teachers to teach English as a second language (DuBay, 2007). The graph originally determined readability through high school. According to Dubay, later the graph was extended to predict the readability of materials meant for primary and college levels. 
Fry graph in Grade level.

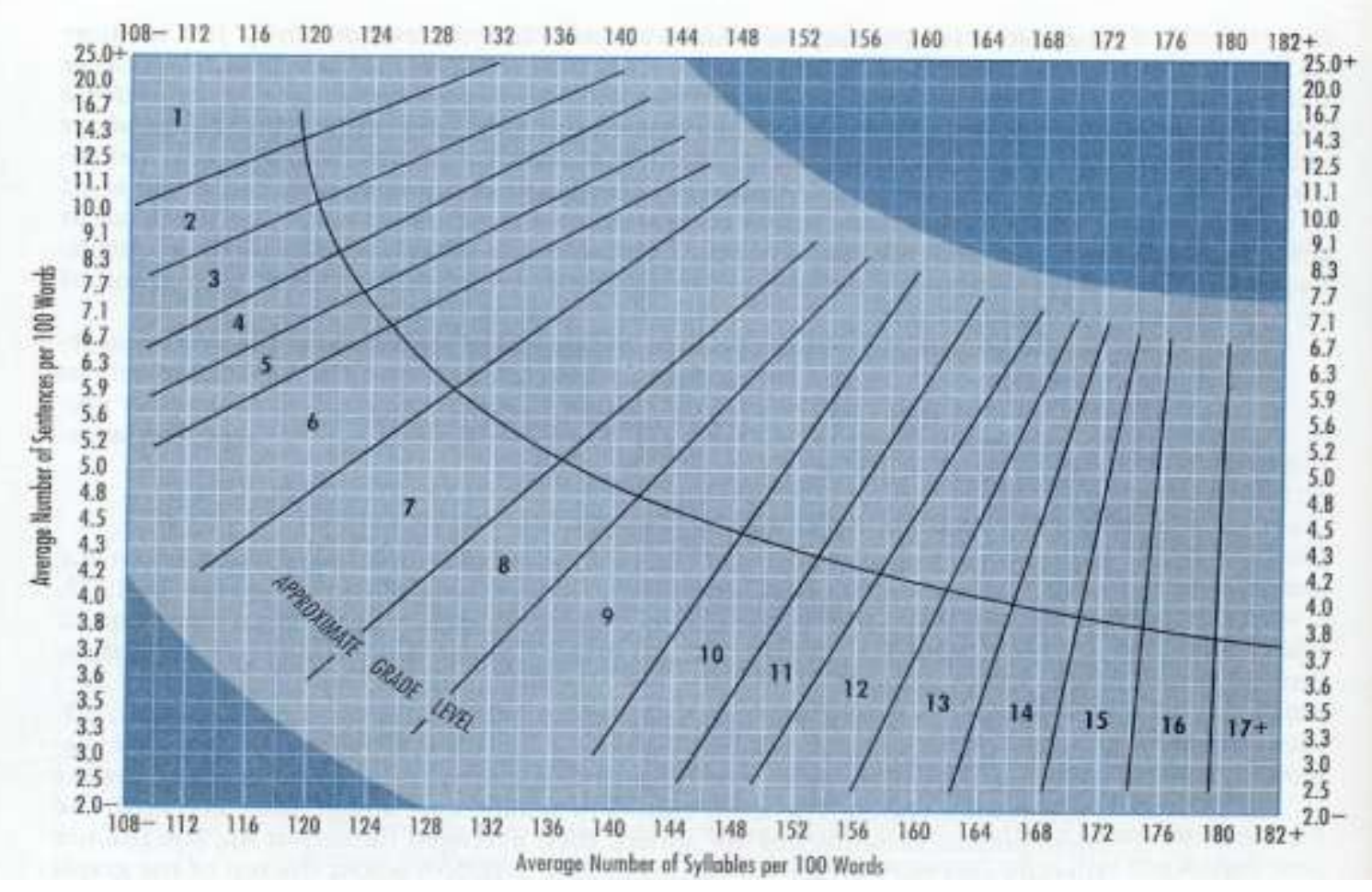

Number of sentences per 100-word passage. Conversely, the horizontal axis indicates the average number of syllables per 100-word. The darks area at the upper and bottom of the graph indicate invalid reading grade level; a text is judged as invalid if the score of Fry readability formula calculation falls into the dark area of the graph (long sentence and long word areas). While the slots where the number 1 to $17+$ are found, are the reading grade level areas.

This Graph involves 100-word passages selected from a book or a text. The average number of syllables and average number of sentences per 100 words is plotted on the graph to determine the grade level. Similar to other formulas, the Fry Readability Graph is dependent on sentences within the passage. However, there is not as much of an emphasis on the number of words or the difficulty of words in the passage.

The using of Fry formula is simple and effective, since it directly points out the grade of user of a particular reading text; the zone where the two coordinate meets will indicate grade of reader (Dubay, 2007). This means that a text with a score of 6 is for grade 6; will be easy for grade 7 and will be difficult for grade 5. In addition, Parker et.al (2001) mention that this formula can help teachers efficiently and with moderate accuracy, select readable texts for wide range of individual student skill levels. 
According to Fry (1977), directions in using his formula are as follows:

1. Randomly select 3 100-word passages from a book or an article.

2. Plot the average number of syllables and the average of sentences per 100 words on graph to determine the grade level of the material.

3. Choose the more passages per book if variability is observed and conclude that the book has uneven readability.

4. Few books, texts, or article will fall into the solid black area, but when they do, grade level scores are invalid.

5. Count proper nouns, numerals and initializations as word.

6. Count a syllable for each symbol. For example, "1945" is 1 word and 4 syllables and "IRA" is 1 word and 3 syllables.

Whereas Dubay (2007) suggests additional directions as follows:

1. Select sample of 100 words.

2. Find y (vertical), the average number of sentence per 100 words passage (calculating to the nearest tenth).

3. Find $x$ (horizontal), the average number of syllables per 100 words sample.

4. The zone where the two coordinates meet shows the grade score.

These two views of direction are complementary. Fry's directions cover assessment of book and text. While Dubay's, accommodates assessment of shorter passages or texts by excluding the "3 100 word passages" direction. Thus, the shorter texts would be possible to assess.

Fry readability formula was validated by several studies done by experts such as Edward Fry himself, Joseph A. Fusaro, and Nasrin Shokrpour. Fry conducted a study to validate his formula when he published his Graph in 1968. He reported that he had used the Dale- hall Readability Formula, among others, for validation purposes. He concludes that although his graph ranked several books as a little easier than the Dale-Chall formula, it was consistent with the Dale-Chall formula (Burkhead, 1974).

In context of this study the Fry readability formula represents is a kind of quantitative approach in measuring readability which relies on two quantitatively measured qualities; vocabulary (e.g., typically assessed by word familiarity and/or the number of letters or syllables within a word) and syntax (e.g., typically assessed by sentence and paragraph length and/or sentence and passage complexity). The using of this formula in predicting text 
difficulty is valid, effective, and has a strong and firm theoretical basis. That is to say, they have been found empirically to do a good job of discriminating text difficulty.

\section{METHODOLOGY}

This study is a descriptive quantitative research. Population of this study was 63 texts that are used to teach reading at Grade IX of MTsN 2 Kota Bengkulu. These texts were taken from three textbooks selected by teacher for teaching; The Bridge English Competence for SMP Grade IX (Yudhistira Press, 2007), Let's Talk (Pakar Raya Press, 2005), and Scaffolding English for Junior High School Students (Pusat Perbukuan Departemen Pendidikan Nasional, 2008). There were 63 texts in the three textbooks used for teaching reading. The distribution of texts within the three textbooks can be seen in the following table;

Distribution of Population (texts).

\begin{tabular}{|l|l|c|c|c|c|c|c|}
\hline \multirow{2}{*}{ No } & \multicolumn{1}{|c|}{ Text books } & \multicolumn{5}{|c|}{ Number of text/genre } & \multirow{2}{*}{ Total } \\
\cline { 3 - 7 } & Descriptive & Narrative & Report & Recount & Procedure & \\
\hline 1 & $\begin{array}{l}\text { The Bridge } \\
\text { English } \\
\text { Competence for } \\
\text { SMP Grade IX }\end{array}$ & 0 & 4 & 7 & 0 & 3 & 14 \\
\hline 2 & Let's Talk & 4 & 3 & 9 & 1 & 5 & 22 \\
\hline 3 & $\begin{array}{l}\text { Scaffolding } \\
\text { English for Junior }\end{array}$ & 0 & 12 & 13 & 0 & 2 & 27 \\
$\begin{array}{l}\text { High School } \\
\text { Students }\end{array}$ & 4 & 19 & 29 & 1 & 10 & $\mathbf{6 3}$ \\
\hline
\end{tabular}

The sample of this research is entire number of the population. The researcher analyzed 63 texts from the three textbooks used by teacher to teach English; The Bridge English Competence for SMP Grade IX (Yudhistira Press, 2007), Let's Talk (Pakar Raya Press, 2005), and Scaffolding English for Junior High School Students (Pusat Perbukuan Departemen Pendidikan Nasional, 2008). There are two main rationales of drawing the total population as the sample in this research. First, Fraenkel and Wallen (2007) state that for descriptive studies, a sample with a minimum number of 100 is essential. Second, Gay et.al (2009) state that for smaller populations, say, $\mathrm{N}=100$ or fewer, there is a little point in sampling; survey the entire population. Based on the two stated rationales, since the total 
number of population was only 63, then it would be more appropriate if the entire number of population is drawn as sample of this research.

The instrument of the current research is Fry Readability Formula (Graph). This formula is used to predict approximate text reading grade level of the sample; it is used for collecting data. By functioning Fry readability formula, the researcher obtained data in form of reading grade level of each text from the three textbook used to teach English for the IX Grade learners of MTsN 2 Kota Bengkulu. There are some rationales in claiming Fry readability formula as an instrument in this research. First, the definition of instrument suggested by Fraenkel and Wallen (2007) which is "instrument is a device used to gather data". Meanwhile, Burkhead (1974), notes that readability formula is a method of measurement intended as a predictive device. Thus, Fry readability formula is the device which both; Freankel and Wallen (2007) and Burkhead (1974) tell about. This is also supported by Chavkin (1997) who mentions that Fry readability formula is a well-known standardized instrument for determining readability that have been used by many educators. Second, there are some researchers who explicitly mentioned that Fry readability formula is the instrument of their study such as Instone (2011) and Hidayati (2005). However, the using Fry readability formula in context of this study could be considered as a standardized instrument. As Gay et.al (2009) notes that a standardized instrument is one that administered, scored, and interpreted in the same way no matter where or when it is used. Fry readability formula is precisely administered, scored, and interpreted broadly in entire the world since 1968.

Data analysis included some steps as; scoring, describing, classifying and interpreting. Texts' approximate reading grade level was calculated through Fry readability formula. The scores gained by Fry's calculation were put in a form that facilitates data classification. Afterward, the data were described to provide a true picture of it, so reader will have a deep understanding on contexts of the research. They were described text by text according to readability calculation (Fry Readability formula). This step leaded to the separation and grouping of data related to different aspects of setting, the classifying phase. In classifying phase, the data were broken down and organized into smaller unit. Tables and chart were employed to make clear the classification of data. Then, in the last phase, the data were interpreted according to the focus of the research. It was referred to the purpose of the research which is to identify the readability of texts used in teaching reading for IX grade students of MTsN 2 Bengkulu; whether the texts are Easy, Meet the Grade, Difficult, or Invalid for IX Grade students of MTsN 2 Kota Bengkulu. 
A particular text was judged as Easy if the score of calculation points out a grade bellow grade 9; a text was judged as Meet the Grade if the score of calculation directly points out grade 9; and a text was judged as Difficult if the score of calculation points out a grade above grade 9; and a text was judged as invalid if the score of calculation points out the dark area on Fry graph (long sentence and word areas). Additionally, since the purpose of the study is to identify texts' reading grade level, then the best and firm way to gain interpretation of data in this research is by using percentage. In order to find out the percentage of texts' grade level classification, the following formula was used;

$$
\mathrm{P}=\mathrm{f} / \mathrm{N} \times 100 \%
$$

$\mathrm{P}=$ Percentage of texts grade level

$\mathrm{f}=$ Frequency of texts' grade levels

$\mathrm{N}=$ The Total Frequency of all texts' grade level

\section{FINDINGS}

Finding of the study indicates that; 34 texts are in Easy classification. It means that $54 \%$ of 63 texts are easy for grade IX students of MTsN 2 Kota Bengkulu. In other words, there are 34 texts are on the range of reading grade level 2 to reading grade level 8 . The chart also implies that there are 6 texts included into Meet the Grade texts. It means that $9 \%$ out of 63 texts meet the demanded reading grade level for IX grade students of MTsN 2 Kota Bengkulu. In other words, there are 6 texts are on the reading grade level 9. Furthermore, the chart shows that there are 17 texts included into Difficult texts. It means that $27 \%$ out of 63 texts are difficult for grade IX students of MTsN 2 Kota Bengkulu. In other words, there are 17 texts are on the range of reading grade level 10 to reading grade level 17+. Finally, chart 1. implies that 6 texts are determined to be Invalid texts. It means that $10 \%$ out of 63 texts are invalid for grade IX students of MTsN 2 Kota Bengkulu. In other words, there are 6 texts do not have reading grade level according to Fry readability formula. 
Percentage of texts reading grade level over the four Interests of the research.

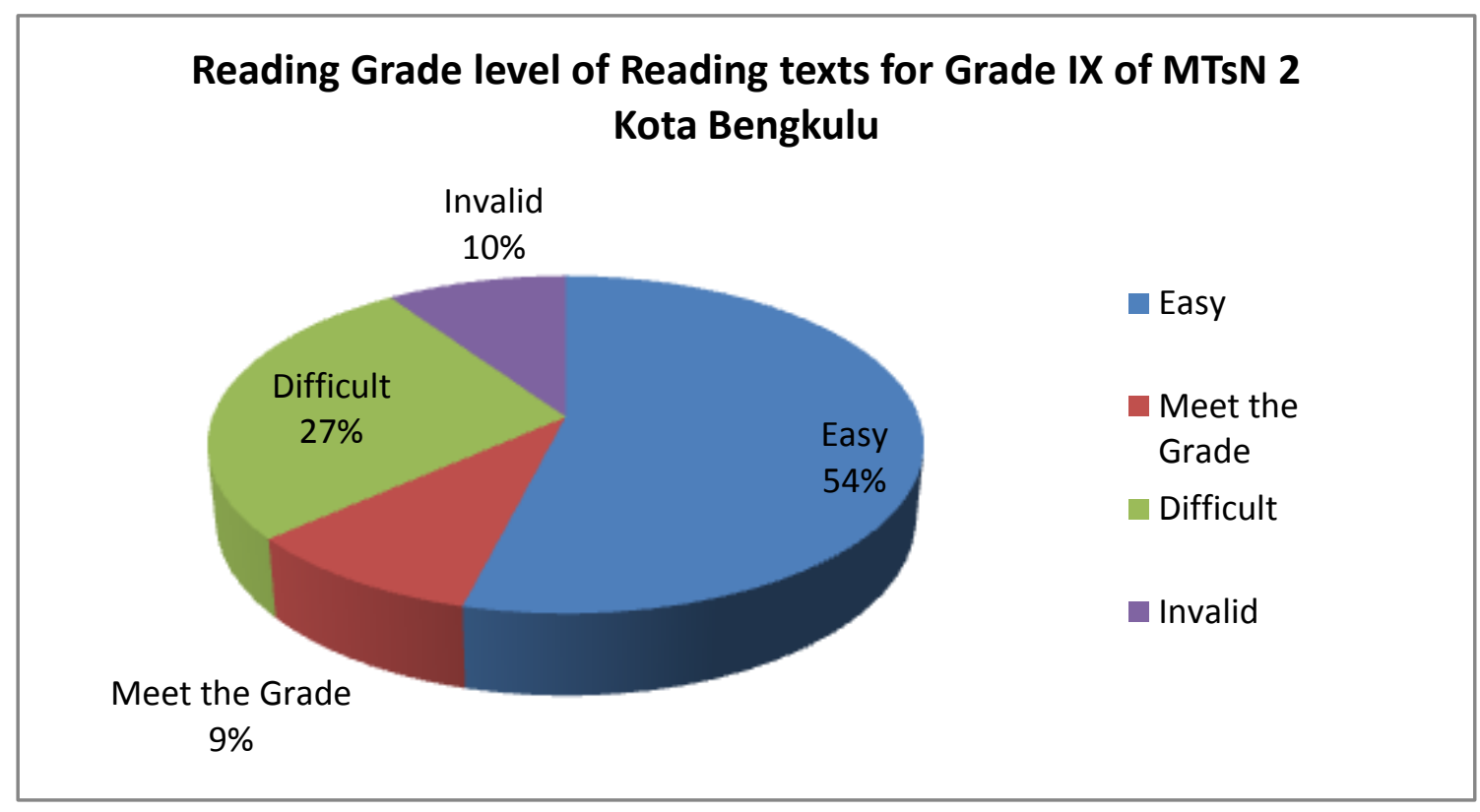

\section{DISCUSSION}

The purpose of this research is to analyze the readability level of texts used in teaching reading for IX grade students of MTsN 2 Kota Bengkulu. The researcher employed a widely used and valid measure to assess the reading grade level of texts used in teaching reading for IX grade students of MTsN 2 Kota Bengkulu, which is Fry readability formula.

Overall, the result of the research implies that; 54\% out of 63 texts (34 texts) are easy to be read by IX grade students of MTsN 2 Kota Bengkulu. Further, there are 17 texts, or $27 \%$ out of 63 texts are difficult for the students. Then $10 \%$ out of 63 texts possess invalid reading grade level. Only $9 \%$ out of 63 texts (6 texts) are in reading grade level 9 , the demanded reading grade level for students grade IX. Regarding to the result of this research, it is clear that the percentage of inappropriate reading grade level of texts (easy, difficult, and invalid) for students grade IX of MTsN 2 Kota Bengkulu is the higher. Then, it can be inferred that the IX grade level students of MTsN 2 Kota Bengkulu were exposed with majority of texts which unfit their reading level.

The result of this research is consistent with the one which was done by Hidayati (2005). Her study was on readability of Biology textbook for grade X students. She analyzed three aspects of the textbook; readability, spelling, and coordination between pictures and contents. In analyzing the textbook's readability the researcher assessed all texts included in the textbook by employing Fry readability formula. Finding of the research indicates that 
readability of text included in the assessed textbook, in general, is not appropriate for X grade students since the percentage of text readability is varied; $60 \%$ of texts are appropriate for Grads X students, $15 \%$ texts are easy, $10 \%$ of texts are difficult, and $15 \%$ of texts are invalid.

In sense of similarity between the current research's findings with Hidayati's, that is, both found a varied proportion of percentages of reading grade level within the four interests of the both studies. However, there is a dissimilarity of the current research in comparison with the above study. The language of texts assessed is different; Hidayati's study assessed texts in Indonesian, while the current research assessed texts in English. Even so, the main field of both studies is still merely the same, which is readability of reading material (text).

At a glance, the percentage of appropriate texts (9\%) in the findings of the current research indicates that the readability of texts used by teachers is seemed to be ignored. In case of the ignorance on reading grade level of texts intended for grade IX students of MTsN 2 Kota Bengkulu to read, it could be caused by the lack of understanding toward concept of readability among English teachers at this school. This makes them skipped readability analysis and simply selected texts for teaching reading without any analysis before using.

The above argumentation was revealed through a mini questionnaire of preliminary research distributed by researcher to several English teachers before starting this research. The questionnaire consists of four items. Each item has five options to choose; Strongly agree, Agree, Undecided, Disagree, and Strongly disagree. These four items were generated from the concept of readability; positive statements on function of readability, methods in measuring readability, and variables used in measuring readability. Nine English teachers from two MTsNs in Kota Bengkulu (MTsN 1 and MTsN 2 Kota Bengkulu) were requested to give their responds on the four statements. The findings of the questionnaire indicate that most of English teachers in the two schools do not possess adequate understanding on the concept of readability. The highest percentage of teachers' respond for each item is on the option of Undecided. This means that most of them did not have a certain idea toward the statement. Reviewing the findings of preliminary research questionnaire done by researcher at MTsN 1 and MTsN 2 Kota Bengkulu, it seems logical if the readability of texts is being ignored.

Apparently, the three concepts; concept of reading, concept of readability and concept of text could not be separated. The relationship among these three concepts can be analogized as; when one is doing reading activity, she is dealing directly with reading material to read, and then the reading material should be fit with her reading ability level, 
otherwise, she may fail to comprehend the reading material properly. It can be noticed that the reading activity is the reading process, reading material is the text, and reading ability level is the readability. Thus, the relationship of these three concepts is like chain which links each others.

Many experts proposed their definitions on the term of reading which mostly implied the complexity of reading process related to the existence of text. For instance one which is proposed by Koda (2004) who states that reading is a complex, multifaceted pursuit requiring the continuous deployment and integration of multiple operations; a depth reading is a constellation of interfaced capabilities, ranging from mechanical mapping to more sophisticated conceptual manipulation, such as reasoning and inferencing. Also, Grellet (1981), states that reading is extracting information the required information from text as efficiently as possible. In addition, Urquhart and Weir (1998) mention that reading means dealing with language messages in written or printed form.

The definition suggested by Koda (2004) focuses directly on the cognitive and neurological operations involved in reading. Whereas Grellet (1981) and Urquhart and Weir (1998) straightforwardly emphasizes that reading involves constructing meaning from written text. The above definitions describe two things; the complexity of reading process and the involvement of text as reading material.

The need of analyzing reading material is caused by the complexity of reading process. This also can be seen from some definitions of readability. Dale and Chall (1949), define readability as "the sum total (including all the interactions) of all those elements within a given piece of printed material that affect the success a group of readers have with it. The success is the extent to which they understand it, read it at an optimal speed, and find it interesting." Furthermore, the creator of the SMOG (Simple Measure of Gobbledygook) readability formula, McLaughlin (1969), defines readability as "the degree to which a given class of people finds certain reading matter compelling and comprehensible". Whereas Pikulski (2002) suggests that Readability is the level of ease or difficulty with which text material can be understood by a particular reader who is reading that text for a specific purpose. All of these definitions are varied in some senses. However, all of them describe a general impression, which is the ease of reading.

In context of teaching reading, the necessity of analyzing reading material is heavily-required. Instead of the reason stated previously, the need of analyzing reading material in teaching reading is tightly related to student's variables such us motivation, reading interest, comprehension achievement, and so forth. If materials are too easy, students 
are unchallenged and bored, and no learning occurs; if materials are too difficult, students are frustrated and withdrawn, and again no learning occurs (Carrell, 1987).

After all, from the brief explanation above, there are some statements can be inferred. First, the reading process is not easy; it is complex and involves many factors. Second, one factor which cannot be separated from reading process is text. Third, one way to make reading process easier and successful is by assessing text with readability concept, which makes possible to provide a reader with an appropriate reading material which fits her reading ability.

Regarding the findings of the current research, based on the theories of the three interrelated basic concepts of the research (reading, readability, and text), it can be stated that the findings are not so ideal. Ideally, the reading grade level of texts assessed should be majority, or even all should be in grade 9 since the reader is students grade IX. In fact, the demanded reading grade level (reading grade level 9) has got the lowest percentage (9\%). Additionally, with a varied percentages as found by the current research, students are provided with a majority of texts which unfit their reading grade level. This is a risky situation in term of students' reading success, motivation, as well as process of teaching and learning reading as was mentioned by Carrell (1987).

\section{CONCLUSION, IMPLICATIONS AND SUGGESTIONS}

Based on the research findings, several conclusions can be drawn. First, from the total number of all the texts (63 texts), most of or 34 texts taught at grade IX students of MTsN 2 Kota Bengkulu are in the range of easy. Second, more than one fourth (a quarter) or 17 texts are in the range of difficult. Third, the minority or 6 texts are in the range of invalid. It means according to Fry's readability formula calculation, the existence of those six texts are not in the reading grade level area. Fourth, there are only 6 texts in ninth reading grade level that appropriate (meet the grade) for grade IX students.

The implications of this research result are; first, the texts which are identified as in reading grade level 9 should be used in teaching reading for IX grade students at MTsN 2 Kota Bengkulu. Second, the texts which are identified as other than reading grade level 9 should be improved and revised. So that their reading grade levels fit to the need of IX grade students (reading grade level 9). Third, alternatively, teachers may find or develop other texts and analyze them with readability measures to get appropriate texts. 
Based on the finding of the study, some suggestions are proposed; first, the English teachers at MTsN 2 Kota Bengkulu are suggested to apply readability analysis on texts before they use them in teaching reading to the IX grade students of MTsN 2 Kota Bengkulu; second, the writers of English textbooks for IX grade students at MTsN 2 Bengkulu are suggested to be aware of readability of texts they included into the textbook they write; and third, other researchers are suggested to conduct further research related to the findings of this research by employing other readability formulas, or other methods of readability analysis.

\section{REFERENCES}

Brown, G., \& George Y. (1983). Discourse Analysis. Trumpington St, Cambrige: Cambrige University Press.

Brown, H. D. (2000). Teaching by Principles; An Interactive Approach to Language Pedagogy. (Second Edition). New York: Addison Wesley Longman, Inc.

Brumfit, C., Geoffrey, B., Roger, F., Peter, H., \& Anita, P. (1978). Teaching English as a Foreign Language. NY: Rougledge \& Kegan Paul Ltd.

Burkhead, Marie B. (1974). A Study of the Readability of Selected Introductory Management Textbooks. Unpublished Doctoral Dissertation, Texas Tech University, Texas.

Carrel, Patricia L. (1987). Readability in ESL. Reading in a Foreign Language, 4 (1), 21-40.

Carroll, J. B. (1964). Language and thought. Englewood Cliffs, NJ: Prentice-Hall.

Chall, J. S,. \& Edgar D. (1949). “The concept of readability.” Elementary English, 26: 23.

Chall, J. S. 1996. Varying Approaches to Readability Measurement. Revue québécoise de linguistique, 25 (1), 23-40.

Chavkin, L. (1997). Readability and reading ease revisited: State-adopted science textbooks. Clearing House, 70(3), 151-154.

DuBay, W. H. (2007). Smart Language: Readers, Readability, and the Grading of Text. Costa Mesta, CA: Impact Information.

Fraenkel, Jack R. \& Norman E. Wallen. (2007). How to Design and Evaluate Research in Education. (Sixth Edition). NY: McGraw-Hill Inc.

Fry, Edward. (1977). Elementary Reading Instruction. New York: McGraw Hill. 
Fry, Edward. (2002). Readability. Retrieved January, 20, 2011, from: http://www.impactinformation.com/impactinfo/fryreadability.pdf

Gay, L. R., Geofrey E. Mills \& Peter Araisan. (2009). Educational Research: Competencies for Analysis and Application. (Ninth Edition). New Jersey: Pearson Education Ltd.

Gerot, L. \& Peter W. (1994). Making Sense of Functional Grammar: Introductory Workbook. Commeray, NSW: Gerd Stabler, Antipodean Education Enterprises.

Grabe, W., \& Kaplan, R. B. (1996). Theory and practice of writing: An applied linguistic perspective. NY: Longman.

Grellet, F. (1981). Developing reading skills. Cambridge, England: Cambridge University Press.

Hedgcock, J. S., \& Dana R. Ferris. (2009). Teaching Readers of English, Students, Texts, and Contexts. Madison Ave, NY: Routledge.

Hidayati, N. (2005). Analisis Buku Biologi SMA Kelas X Semester I Berdasarkan Kurikulum 2004 Yang Banyak Digunakan di SMA Negeri Kabupaten Batang. Unpublished Undergraduate Study. Universitas Negeri Semarang, Semarang.

Instone, E. (2011). The Variance Amongst the Results of Readability Formulas Regarding U.S History Textbook. Unpublished Graduate Study. Bowling Green State University, Northwest Ohio.

Klare, George R. (1968). The Role of Word Frequency in Readability. In J. R. Bormuth (Ed), Readability in 1968 (pp. 7-17). Chicago: National Council of Teacher of English.

Koda, K. (2004). Insights into second language reading: A cross-linguistic approach. Cambridge, England: Cambridge University Press.

McLaughlin, G. H. (1969). SMOG grading: a new readability formula. Journal of reading, 22:639-646.

Oakland, T. \& Holly B. Lane. (2004). Language, reading, and readability formulas: Implications for developing and adapting tests. International Journal of Testing, 4: 239-252.

Parker, Richard I. , Jan H. E. \& Laurie W. (2001) Spanish Readability Formulas for Elementary Level Texts: A Validation Study. Reading \& Writing Quarterly, 17: 4, 307- 322

Pikulski, Jhon, J. (2002). Readability. Litho: Houghton Mifflin Company.

Richard, Jack C., \& Richard Schmidt. (2002). Longman Dictionary of Language Teaching \& Applied Linguistic. (Third Edition). London: Pearson Education Limited.

Smith, F. (2004). Understanding reading (6th ed.). Mahwah, NJ: Lawrence Erlbaum. 
Ulusoy, M. (2006). Readability Approaches: Implication for Turkey. International Education Journal, 7 (3), 323-332.

Wallace, C. (1993). Reading. Oxford: Oxford University Press.

Wolf, M. (2007). Proust and the squid: The story and science of the reading brain. New York: HarperCollins. 